CATALAN REVIEW

Catalan Review

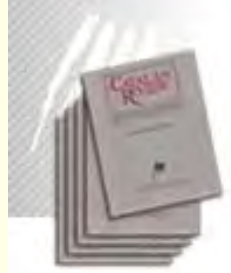

You are accessing the Digital Archive of the Catalan Review Journal.

By accessing and/or using this Digital Archive, you accept and agree to abide by the Terms and Conditions of Use available at http://www.nacs-

catalanstudies.org/catalan_review.html

Catalan Review is the premier international scholarly journal devoted to all aspects of Catalan culture. By Catalan culture is understood all manifestations of intellectual and artistic life produced in the Catalan language or in the geographical areas where Catalan is spoken. Catalan Review has been in publication since 1986 .
NORTH

AMERICAN

CATALAN

SOCIETY
Esteu accedint a l'Arxiu Digital del Catalan Review

A l' accedir i / o utilitzar aquest Arxiu Digital, vostè accepta i es compromet a complir els termes i condicions d'ús disponibles a http://www.nacs-

catalanstudies.org/catalan_review.html

Catalan Review és la primera revista internacional dedicada a tots els aspectes de la cultura catalana. Per la cultura catalana s'entén totes les manifestacions de la vida intel lectual i artística produïda en llengua catalana o en les zones geogràfiques on es parla català. Catalan Review es publica des de 1986.

\title{
Mediterranean Classicism and Sculpture in the Early Twentieth Century Marilyn McCully
}

Catalan Review, Vol. V, number 1 (July, 1991), p. 145-167 


\section{MEDITERRANEAN CLASSICISM AND SCULPTURE IN THE EARLY TWENTIETH CENTURY}

\section{MARILYN MCCULLY}

Aubouro te, raço latino

Souto la capo dou soleu!

Lou rasin brun boui dins la tino

Lou vin de Dièu gisclara leù.

«A la Raço Latino», Frédéric Mistral ${ }^{\star}$

At the now celebrated Salon d'Automne in Paris of 1905 , the exhibition of a plaster female nude, ${ }^{2}$ which came to be known as La Méditerranée, by the French Catalan sculptor Aristide Maillol, heralded a new direction in sculpture. Although Maillol's figure, which was exhibited beneath one of Le Douanier Rousseau's jungle paintings, was acclaimed by André Gide (Gazette des Beaux Arts), Octave Mirbeau (La Revue des Revues) and, above all, Maurice Denis (Occident), its importance was given far less attention in the press than it merited, mainly because of the scandal of the so-called Cage aux Fauves in the same show. Yet sculptors, who had until that point been overshadowed by the presence of Rodin, saw in this single work the possibility of escaping the nineteenth-century attitudes of romantic heroism that the older artist's work embodied: his

i «Rise up, Latin race, under the canopy of the sun! The brown grape is seething in the vat, the wine of God will soon gush forth». Refrain of Mistral's poem «A la Raço Latino», reprinted in the special «Félibrige» number of La Plume, I July r891.

= The work was later executed in stone for Maillol's future patron, Count Kessler, and also cast in bronze for the Municipality of Perpignan, where it was placed in the patio of the Hôtel de Ville; yet another version in stone was subsequently placed in the Tuileries Gardens in Paris. 
emphasis on drama, sensuality and mood through exaggeration; and his evocation of the changeability and power of nature through the sculptural handling of materials and surfaces that catch the changing aspects of light. In place of this, Maillol's work gave life to a new kind of Mediterranean classicism.

Until then the only real alternative to the model of Rodin, apart from the still flourishing tradition of salon statuary, was decorative, architectural sculpture, which at that period was heavily influenced by the organic forms of Art Nouveau. But Rodin's own disciples, Bourdelle, Despiau, and above all Maillol, were already beginning to challenge these models, emerging with an art based in ideas of harmony, solidity and proportion. Studies of a crouching woman relating to La Méditerranée had been begun in the spring of I900; according to Maillol's biographer, Judith Cladel, the sculptor was preoccupied with balancing the masses of the human body within a roughly square, overall shape, first modelling and then making various casts in a manner he would later teach to Matisse. ${ }^{3}$ Maillol continued working on the figure, variously entitling the finished piece Statue pour un Jardin ombragé, later La Pensée, followed by La Pensée Latine, and finally La Méditerranée.

This shift away from Romanticism, late nineteenth-century symbolism and Art Nouveau to Mediterranean classicism in the work of Maillol and his fellow sculptors was symptomatic of a far larger and more general trend in art and literature, which left its mark not only in France, but on regions such as Catalonia, where the idea of the Mediterranean came to represent a movement that was both cultural and political. In part the shift can be accounted for as a self-conscious new beginning for a new century: the decadent years of the nineties were over, and artists and writers alike looked optimistically ahead for a new sense of order in both art and society to express a 
new, twentieth-century spirit. In fact, in Catalonia the movement was named (in I906) «Noucentisme», a word used like the Italian «Novecento» to refer to art and culture «of the twentieth century».

However, the origins of this «Mediterranean» classicism can be traced back to the nineteenth century, and in particular to regionalist movements that became increasingly active in the last decade. When Maillol for a time called his figure La Pensée Latine, he explained that this was a «terme qu'il faut prendre dans le sens où l'entend Charles Maurras»." What Maillol meant by this qualification was quite specific: the Provençal Maurras was the most outspoken critic representing the new wave of Mediterranean classicism in literature (and increasingly in politics) that had accompanied the literary École Romane (Romance School), in which the French-Greek symbolist writer Jean Moréas was the moving spirit. Maillol's identification of his work with this movement-and the close association of the Catalan sculptors Enric Casanovas, Josep Clarà and others with the parallel Noucentista movement-allows us to trace a source for their sculptural style; and, moreover, the development out of the symbolist movement of a new kind of «classicism» in literature offers a pattern that we can see followed by painters as well as sculptors.

On I January r89r, Léon Deschamps, editor of La Plume, published a special number dedicated to the Symbolism of Jean Moréas, to celebrate the publication of his new collection of poems Le Pélerin passioné; it included laudatory essays, a selection of poems as well as the author's preface to his new work, and a portrait of Moréas by Gauguin inscribed «Soyez Symboliste». Yet, within a matter of weeks Moréas stupefied many of his followers by announcing at a banquet held in his honour that Symbolism was dying. It was only a stage of transition, he claimed, towards reestablishing the natural course of French 
literature: that is, to follow in the tradition of medieval Romance literature with its Greco-Latin roots. Nineteenth-century Romantic literature (like art) was an interruption in the natural progression and development of the French language, and the Parnassians, Naturalists and Symbolists in the late nineteenth century were the decadent consequences of this break in the Romance tradition. Now, Moréas went on, writers must return to purity and dignity in the language; and he cited a few of his contemporaries, including Ernest Raynaud, Maurice du Plessys and Charles Maurras, who shared this ideal of Romanité. ${ }^{s}$

A special issue of La Plume later that year ( $\mathrm{I}$ July I89r) was devoted to the Félibrige, with Maurras as guest editor. Here, unequivocally, Moréas's new direction in poetry was linked to the Provençal regional movement; and this movement was to be given a new more openly political direction by Maurras and his fellow Jeunes Félibres. The original Félibrige society had been formed in Aix-en-Provence in 1854 by a group of poets, including Frédéric Mistral, to protect the language and the national honour of Provence. (The Provençal word «Félibre», a discovery of Mistral's, originally meant a Doctor responsible for interpreting the law.) Maurras, now twenty-two and a leading member of the Parisian Félibres, was an enthusiast, and his number of La Plume showed clearly the route he wanted the movement to take. He reprinted poems by Mistral, including his rallying cry «A la Raço Latino»-in which four stanzas, each with the refrain «Rise up, Latin race...» praise respectively, the race, the language, the women and the earth, and the sea

5 The ideology of the École Romane had, in fact, already been set out in the "Annales de Symbolisme» contributed by Achille Delaroche to the Symbolist number (I January I89I) of La Plume: «Renouons donc, par dessus les âges dits classiques, la vraie tradition de la bonne langue française. Chez les Gothiques, en vérité, gisent, enfouis sous la poussière des siècles, des trésors idoines à vêtir de splendeurs les idées et les sentiments les plus complexes de l'âme moderne». 
of Provence. There were also poems by other Félibres, including a Mistral imitation by Moréas, accounts of societies in different parts of France and, in conclusion, a provocative essay by Maurras entitled «Barbares et Romans», which called for a purification of French culture, attacking the Romantics and their heirs who were dominated by the «âme slave», the «âme allemande» or the «âme anglaise». ${ }^{6}$ Within a year Maurras had split the Félibres by issuing his «Déclaration des Félibres fédéralistes», which called on the movement to take on a political role, fighting for a federal constitution in France with autonomous provincial assemblies. Although the Déclaration was immediately published by Mistral in L'Aioli (7 March 1892 ), Maurras was later expelled from the society, and with the foundation of the royalist movement "Action Française» in 1899 , his views became increasingly extreme-though he continued to have a loyal following. ${ }^{\text {? }}$

The aims of the École Romane were less dramatically set out by Ernest Raynaud in the Mercure de France in May I 895: «Le retour dans la pensée comme dans le style à l'équilibre et à l'harmonie... Nous avons entrepris de défendre le patrimoine des muses latines, d'opposer le goût d'ordre, de mesure et d'harmonie de notre race aux imaginations monstrueuses, à l'inconcevable chaos de l'étranger, et de lutter, dans la mesure de nos forces, pour le salut de l'esprit français et le règne de la beauté». The intellectual influence of this school, quite apart

${ }^{6}$ Shakespeare was retained in the pantheon, since his work was, in Maurras's opinion, so completely infused with the Italian spirit.

7 Mistral still regarded Maurras as his apostle as late as 1909: in that year he wrote of him: «A moun ami Charles Maurras que mies que touti e sus touti a coumpres e esclargi l'ideio de ma vido». See: Études maurrassiennes r: "Charles Maurras et la vie française sous la troisième Républipue [sic]», Aix-en-Provence 1972 , 87. Maurras founded the newspaper Action Francaise as a daily in 1908 , and it subsequently played an important role in rallying pro-French, anti-German sentiment during the first World War, while the racist element of Action Française (set in terms of nationalism, or Mediterraneanism) dominated its rhetoric. 
from Maurras's political activity, was especially potent for artists who had espoused Symbolism, who maintained active contact both among themselves and with writers in turn-of-the-century Paris: Maillol, for instance, had met Gauguin and his circle as early as 1892 and was particularly friendly over the ensuing decade with the Nabis. Denis in particular had appreciated the decorative, essentially flat style Maillol had developed in tapestry design, and classicizing trends can be found in Denis's own work that parallel those in the development of Maillol's career as a sculptor. By the time Picasso and other young Barcelona artists arrived in Paris for the Exposition Universelle in $I 900$, they found symbolist art in the throes of change.

Painters affected by the Mediterranean ideal included, among others, Renoir and Cézanne, both of whom were undoubtedly well aware of the activity of the Félibrige. ${ }^{\mathrm{B}}$ And it is to Cézanne, in particular, that many of the classicizing undercurrents to be found in early twentieth-century painting in France can be traced, not only because of the influence of his Bathers, who evoked their classical heritage in a modern context, but for his radical attitudes towards the structure of composition and technique." The exhibitions of work by the Master of Aix, beginning in the salon d'automne of 1904 through the great retrospective of 1907 (the year after his death), challenged a whole generation of painters, and certainly to some degree, sculptors, Maillol among them. Even among the so-called Fauves, Matisse and Braque quickly turned to classical themes and to questions of compositional structure and harmony. Significantly, the same structural trend, even the sub-

${ }^{8}$ On Renoir, see John House, «Renoir's Worlds», in Renoir, London, 1985, 18 n. 76; while Joachim Gasquet, an enthusiastic Félibre, became a good friend of Cézanne and one of his principal correspondents in the last ten years of his life; see John Rewald, Cézanne Letters, New York, 1976, $244 \mathrm{ff}$.

- For an extensive and illuminating discussion of the theme of bathers in the work of Cézanne, see: Mary Louise Krumrine, Paul Cézanne: The Bathers, Basel, r989. 
ject of bathers (in Picasso's work of I908-1909) as well as the interest in the archaic, also underlies the developments leading up to Cubism. And, in contrast to the expressionism of early abstract painting and in spite of its revolutionary nature, Cubism itself was regarded by a number of critics as «classical». ${ }^{\text {.0 }}$

Federal policies, like those of Maurras, were actually realized in Catalonia, where the regionalist movement, despite its factions, was a serious political force. While the Catalan cultural movement had many connections and had maintained close links with the Félibrige, ${ }^{\text {" }}$ throughout the 1890 os the more pragmatic Catalanist politicians were determined to get significant concessions from the weak and corrupt central government in Madrid for what was the most prosperous, the most energetic and the most internationally-minded region of Spain. Here, then, was a difference; for while internationalism was anathema to Maurras's Provençal Federalists, it gave credibility to the Catalanists. There were other conflicts too, despite the affinities between the Catalan and Provençal languages and the fact that Catalonia's boundaries spanned the political boundary between Spain and France, so that even for these close neighbours it was not always easy to see eye-to-eye on the ways to promote the Latin, Mediterranean ideal. A wider pan-Latinism, in the years before World War I at least, created more problems still, since Spain as a whole would be unwelcome to the Catalans,

to The Catalan critic Josep Junoy, a great promoter of Mediterraneanism in the second decade, defended Picasso's Cubism as classical in his essay, "De Paul Cézanne a los "Cubistas"”, in Arte \& Artistas, Barcelona, I9I 2. $"$ In 1866 , for example, the Catalan poet Víctor Balaguer, who advocated a wider Félibrige, had joined the group as a political exile from Spain, and festivals and poetic offerings were exchanged between the two groups well into the next decade. On the occasion of the fiftieth-anniversary of the founding of the Félibrige, the Modernista journal Joventut published an Artistic Supplement to the $26 \mathrm{May} \mathrm{I}_{904}$ issue, as well as a message from Mistral to the editors on the occasion. 
while Italy's political stance made it unacceptable to the French. The Catalans and Provençals had to take comfort in the fact that as they could argue, the Greco-Roman traditions (including the Catholic church during the time of the Avignon papacy) had been preserved with greater purity on the northern shore of the Mediterranean, less polluted by Barbarian influences, until their ancient kingdoms had been annexed in the late fifteenth century by Spain and by France.

Once the Catalans were beginning to gain political power, ${ }^{12}$ the pure Mediterranean ideal began to take hold more firmly. Noucentisme, the principal theoretical movement in the arts and in politics in Catalonia in the first two decades of the twentieth-century, shows the impact of la pensée Latine on Catalonia's own regional movement. Noucentisme was articulated principally by the writer Eugeni d'Ors in his regular column, known collectively as the Glosari (I906-I92I) in the Catalan-language newspaper $\mathrm{La}$ Veu de Catalunya. Following the example of Maurras, d'Ors saw the new art as a metaphor for society, returning to its Greco-Latin roots for inspiration. And as a regional movement, Noucentisme essentially aimed to purify Catalan art-as a model for a new Catalan society-by reasserting its «Mediterranean» identity and cultural heritage as separate from the rest of Spain.

As part of his linguistic strategy in defining Noucentisme d'Ors identified a new, twentieth-century spirit in the arts and society which was quite distinct from the decadent, fin-de-siècle movement-Modernisme-from which he and his generation had themselves emerged. Artistically-in literature, music,

12 Catalanism gained momentum during the first decade of the new century-that is, during the formative years of Noucentisme: in I90I the Catalanist political party, the Lliga Regionalista, won its first parliamentary seats; in I 905 Prat de la Riba published La Nacionalitat Catalana, proposing a Catalan state within a Spanish federation; and by I9II this was made a reality with the formation of the Mancomunitat, an autonomous body representing Catalonia, with Prat de la Riba as president. 
architecture and the visual arts-turn-of-the-century Modernisme had put Barcelona as capital of Catalonia on the world map of arts, for the city flourished and developed as the home of a style, which shared many characteristics with other centres of art at that time, but produced its own unique architectural style and variations in the other arts of prevailing international tendencies. The highpoint of Modernisme came in the I 890 s with the Festes Modernistes organized by Santiago Rusiñol in the coastal village of Sitges. These celebrations (held between 1892 and 1898 ) included exhibitions of painting as well as musical and literary events - the composer D'Indy was an invited guest, Maeterlinck's L'Intruse was performed in Catalan translation, Loie Fuller's serpentine dance was performed on the sea, and a Catalan opera inspired by Wagner produced. In addition, the rediscovery of El Greco was commemorated with the installation of a statue of the painter on the seafront, and Rusiñol's renovated home, called the Cau Ferrat, was dedicated as a temple to the new art. The heady symbolist atmosphere of Sitges Modernisme was then transferred in the late nineties to the Montmartre-style café Els Quatre Gats, where personalities as diverse as Picasso, Manolo and d'Ors got their start in the bohemian world of turn-of-the-century Barcelona. There, in addition to the exhibitions (Picasso showed there twice in I900), music and poetry readings, young artists and writers had a hand in the production of experimental shadow-puppet theatre or in the publication of art journals (Luz, Quatre Gats, Pèl \& Ploma). No less important were the endless discussions at the café tables about art, literature and philosophy and about the direction that the new generation of Catalonia's intellectual and artistic world should take in the new century.

Today, outside Catalonia, the term Modernisme (in art and architecture) is often mistakenly used as if it were simply a translation of «Modern Style» or «Art Nouveau», with Gaudí seen as a Catalan Guimard or Horta. But Gaudí was a deeply conservative Catalanist who loathed the decadence of inter- 
national fin-de-siècle art, especially the circles around Rusiñol in Sitges and at Els Quatre Gats. This simplistic view of Modernista art (which altogether neglects literature) also overlooks its deep roots in the Catalan regional movement of the nineteenth century, as well as its connections with contemporary ideas stemming from beyond its borders-to include French symbolism, the philosophy of Nietzsche and many of the artistic theories of Wagner, of William Morris and others. Moreover, and contrary to much of recent Catalan scholarship concerning the art and architecture of this period, ${ }_{2}{ }^{13}$ it must be remembered that, for all d'Ors's rhetoric, Noucentisme was a development out of Modernisme, not just a rejection of an older generation and what it stood for. In particular, the support for Modernisme had been found among the large Catalan bourgeoisie, whose money funded the expanding city, its new buildings and cultural undertakings, just as the political regionalist movement expressed their interests and aspirations.

Now that these were beginning to be realised, a new sense of order was called for. It was here that the Latin, Mediterranean, movement began to play its part. By 1905 Moréas felt that his ideas had won through in France, for he said: «Mon instinct n'avait pas tardé à m'avertir qu'il fallait revenir au vrai classicisme et à la vraie antiquité... Aujourd'hui j'ai le plaisir

13 Oriol Bohigas, quoted in Història de l'Art Català, vol, VII, Barcelona, 1985,168 , regards Noucentisme as a reaction against the avant-garde that Modernisme had engendered. This view tends simply to oppose the two movements. Francesc Fontbona, in La crisi del modernisme artístic (Barcelona, 1975), inserts an artificial period between the two artistic movements, which he, somewhat confusingly, calls «post-modernisme». More recently, Teresa Camps in her excellent essay, «El nostre primitivisme», in the exhibition catalogue L'Avantguarda de l'escultura catalana (Barcelona, 1989), questions these distinctions, preferring to see artistic Modernisme and Noucentisme more closely tied together over the first decade of this century. I am especially indebted to her stimulating discussion of the concept of early twentieth-century primitivism and the classical movement, and to her pioneering research in this area. 
de constater que tout le monde revient au classicisme et à l'antique. $\gg^{t 4}$ But he was still able to help further his ideas abroad, especially in Catalonia; in 1906 Moréas apparently spent hours in discussion with Eugeni d'Ors and other Catalan artists in Paris, such as the sculptor Manolo Hugué, ${ }^{15}$ precisely at the time d'Ors was formulating (or perhaps one should really say, appropriating) the theoretical basis of Noucentisme.

Maillol was not actively involved in the Catalan movement in Spain, but he did apparently pay quite frequent visits to Spanish Catalonia ${ }^{16}$-apart from the months he spent each year in this native Banyuls - and he also associated with the Catalan colony of artists and writers who flocked to Paris and actively worked there in the fifteen years or so prior to World War I. ${ }^{17}$ Indeed, after the exhibition of La Méditerranée in 1905 (which was listed in the salon catalogue simply as Femme), many Catalans, including the sculptors Clarà and Casanovas, as well as d'Ors, made a point of visiting and paying tribute to their «kinsman» (i. e. fellow Catalan) in his studio. Moreover, Maillol's new classicism was also seen as part of a new art movement, particularly since his work had been shown at some of the progressive galleries. In 1902 he had exhibited alongside the Basque sculptor Paco Durrio at Berthe Weill's; and later the same year, Vollard gave Maillol his first individual show of 33 works, including 22 sculptures, which drew the attention of the critic Félicien Fagus as well as the admiration of Rodin. ${ }^{\text {i8 }}$

${ }_{44}$ Jean Moréas, quoted in G. Le Cardonnel and Ch. Vellay, La Littérature contemporaine, Paris, 1905, 38.

${ }_{15}$ Montserrat Blanch, Manolo, Barcelona, 1972, 19.

${ }^{16}$ Henri Frère, Conversations de Maillol, Geneva, 1956, 61. Maurice Denis also wrote in 1910 about a visit Maillol paid to Girona; Lectura I, Girona, I9I0.

${ }_{17}$ Maillol later claimed that Picasso came to see him at his studio in Villeneuve Saint-Georges on his first visit to France (it was more likely his second visit in 1901), and that he sang to Maillol in Catalan; Cladel, 153.

${ }^{18}$ Rodin reportedly commented on Maillol's rog2 exhibition: «Je ne 
After Maillol's success at the I905 Salon, he continued to develop the idea of Mediterranean classicism in his sculpture, first by elaborating the image of the female nude, inspired, as he later said, by memories of the Catalan women of Banyuls. Their strength and simplicity seemed somehow closer to the women of Greco-Latin cultures; and he conveyed this in the well-proportioned, somewhat heavy-legged figures that predominate in his work thereafter. Just after the Salon, he also received his first major commission-for a memorial to the revolutionary nineteenth-century socialist, Louis-Auguste Blanqui-from a committee that had included Clemenceau and Anatole France (author of one of the panegyrics of Moréas in the I January I89I issue of La Plume) as well as the critics Mirbeau and Geffroy. The full-length twisting nude he created, known as L'Action Enchaïnée (completed in 1906 , but not installed for another two years), is based on this same figure type: the massive torso is emphasized by the positioning of the manacled hands behind the figure and by the turning head which counters the forward thrust of the front leg. But this symbolic, powerful movement becomes tempered in the nudes that follow in Maillol's evolving style, especially after his 1908 trip to Greece. After that his image is, in a sense, set, and all the sensual, strong women who follow are variations on the essentially Mediterranean type. The fact that Maillol's work was seen to continue the values of twentieth-century classicism for years to come led to its ultimate association with reactionary French nationalism (even if Maillol may not have intended it to do so) in its various manifestations.

Noucentista classicism in the arts in Catalonia during the

connais pas dans toute la sculpture moderne un morceau qui soit aussi absolument beau que la Leda, aussi absolument chef-d'oeuvre»; see: Hommage à Aristide Maillol, Paris, I96I, 10. It was also during the Vollard show that Maillol met Count Harry Kessler. Félicien Fagus wrote about Maillol twice in 1902 (January and August) in Revue Blanche. 
first decade of the twentieth century shared many of the same characteristics as the emerging movement in France. The image of a modern Mediterranean Arcadia became the subject of writers, painters, and especially sculptors, who celebrated women as heroines in forms which in themselves evoked their distant heritage. The Catalans, however, looked further back for their models, in particular to archaic rather than classical Greek sources. In the archaic-what they termed «primitive»- ${ }^{19}$ the Noucentistes saw a more direct link with their ancient past, and contemporary archaeological excavations made this link seem more immediate. Like the École Romane, Noucentisme repudiated the classicism of the seventeenth and eighteenth centuries and the neo-classicism of the nineteenth. But by replacing these, to them, corrupted versions of the classical ideal with harmonious, well made and ordered forms, Noucentista artists could synthesize and express the many levels of experience of the modern world. In this way the «archaic» or «primitive» classicism which inspired the new forms was seen as modern among the Noucentistes. Miguel Utrillo, writing on the idea of primitivism and the sculpture of Enric Casanovas in 1912 , for instance, regards the taste for the primitive, bound to the example of ancient Greece, as one of the principal characteristic currents of the new century. And he ends his piece: «Art recovers new strengths when it is supported on the soil of mother earth».. Mistral's ideals of the race, the language, the woman of the land and the Mediterranean take on a new force.

Imbued with the spirit of a new beginning, the first issue of the Catalan journal Futurisme (1907) proclaimed: «We are the men of tomorrow; we are the future... (and) we put ourselves

19 See Camps for a discussion of the connotations of the term «primitive» in early twentieth-century Catalan art.

20 Miguel Utrillo, «El primitivismo», Museum II, No. I, Barcelona, I9I 2; quoted and discussed in Camps, 20. 
and all of our energy and youth at the service of Catalan art. It is useless to say that we are nationalists, since making art is patriotic. We wish our art to have the stamp of «la terra catalana». And the painter Torres García (an Uruguayan working in Barcelona), who opened a school, claims in the same year, «We must turn to our own Mediterranean tradition of art and leave behind French impressionism, English preraphaelitism, German symbolism... even if they are still in fashion, because they do not arise from here. We must return to the art that originates on our soil.... ${ }^{21}$ But beyond the calls of the artists, the ideas implicit in Noucentisme were to form the whole structure of Catalan politics.

During the first two decades, the growing power of the autonomous Catalan government also led to a widespread organization of all cultural and educational activities in the name of order and social harmony. As Alan Yates has commented, after Modernisme, «Noucentisme transmuted cultural revolution into an efficient programme of cultural institutionalization»..2 For instance, the Catalan language was standardised (Pompeu Fabra published his dictionary in 1917), the Library of Catalonia and an autonomous Catalan university were established, and schools of dramatic and decorative arts were opened. The conscious programmatic link with Mediterraneanism was made in the area of archaeology: in 1907 the archaeological section of the Institut d'Estudis Catalans initiated the historical and methodological investigation of Roman Barcelona; and in I909 excavations at Empúries were begun on the North Catalan coast. These both stimulated archaeological interest in Catalonia's ancient past and also gave artists immediate examples of their own artistic heritage.

* Joaquín Torres García, «La nostra ordinació y el nostre camí», Empori I, Barcelona, 1907; quoted in Camps, 36 .

"Alan Yates, «Catalan literature between Modernisme and Noucentisme», Homage to Barcelona, London, 1985, 258. 
Eugeni d'Ors had by the end of the first decade firmly established himself as the self-appointed pontificator of Noucentisme. His Glosari had, since he had first gone to Paris in I906, informed his readers of intellectual, artistic and scientific developments in France and of the parallels to be drawn in those models with the development of a new Catalan society. Moreover, in his columns he had begun to «nominate» representative Noucentistes in a variety of fields; and in I9I I he published his now celebrated Almanach dels Noucentistes, in which he grouped Catalan writers and artists (including Picasso) alongside the likes of Homer and Goethe. D'Ors included the latter as a representative great thinker whom he personally admiredhis Latinism always allowed some leeway for German philosophy-but the Mediterranean bias of his selections was strong. The title page reproduced the head of the recently excavated Venus of Empúries, a selection from Homer was reproduced in Greek and then translated into Catalan, and Francesc Sitjà wrote an article, «De l'art classich», in which he attempted to connect the mythological spirit of the Catalan past with Noucentisme. D'Ors's choice of illustrations reflected rather less of the classicist direction in form than in content: the female nude (the sculptor Clarà is represented by a drawing of a Maillol-like standing nude), maternities, domesticity (Picasso is represented by a 1905 Saltimbanque family engraving), and la terra catalana.

In I9I I d'Ors also gave literary form to the principal Noucentista image: La ben plantada (literally, like a tree, the well planted or firmly rooted girl). A series of his columns (published in r 9 r 2 as a book) was devoted to a philosophicalliterary description of the ideals of Noucentisme as expressed in the form of a mysterious woman called Teresa, who stands for her (Latin) race. D'Ors first sees the imaginary young woman in the summer of I9I I at a small, Catalan seaside village. He describes her in detail: she is one metre eighty-five centimetres tall, her legs are long in proportion to her torso, she is full- 
breasted, and she moves with grace, etc. Why have the village men not noticed her before, d'Ors asks, and where does she come from? It turns out that Teresa, although her parents are Catalan, was born in Paraguay and only arrived in Catalonia in 1909-the year, d'Ors later points out, of the murderous and destructive anti-clerical riots (the so-called Setmana Tràgica) in Barcelona. Teresa then is a modern woman who represents in all her serenity, Hellenic qualities and worldliness, in addition to her pure Catalan racial stock, a return to order and harmony.

For his physical description of Teresa, d'Ors may well have been inspired by specific artistic images of women he saw in the I9I I exhibitions at the Faianç Català galleries: sculptures by Clarà (April-May) and Casanovas (October-November) made an enormous impact and were championed as expressive of the new society and its aspirations. Clarà, whom d'Ors had visited in Paris and had nominated as a Noucentista in r909, and Casanovas had created figures that already embodied the idea of the well proportioned ben plantada: not only did they recall ancient art, but they were also perceived as modern by the Noucentistes. In the case of Clarà, it was certainly his emulation of Maillol that conveyed the idea of a new Mediterranean classicism in the form of the female nude.

Josep Clarà, a native of Olot in the heartland of Catalonia, had gone to Paris in 1900 at the time of the Universal Exhibition. He first became a disciple of Rodin, and under his tutelage developed a style which won him invitations to international exhibitions and the occasional acquisition by the French state. But by 1909 Clarà, like so many of his contemporaries working in Paris, had shifted allegiance from Rodin to Maillol. D'Ors was quick to appropriate Clarà's classicism to support his ideas about Noucentisme. «Today», Clarà told d'Ors, sculpture «is moving in the direction of balance and harmony (regularidad) as the last vestiges of the superstition about the spontaneous 
disappear». ${ }^{23}$ The reference to spontaneity undoubtedly refers to Rodin, and the new direction to Maillol. Clarà's emulation of the French Catalan was to affect everything he would subsequently produce, even when the message of the work was specifically intended to express Noucentista ideals. Although Clarà remained in France until 1932 , he maintained close relations with artists in Barcelona and helped found the group called Les Arts i els Artistes, taking part in their first exhibition (I9I0) at the Faianç Català galleries. «An art of structures» is how d'Ors described his classicism in La Veu de Catalunya (24 July) in r9ro; and in the following year, the brilliant young critic Josep Junoy observed that «his busts of women recall in spirit certain marble heads by Praxiteles and Scopas. Nevertheless, Clarà is mainly interested in everything that has to do with the construction and architecture of his forms. He is constantly assembling. He balances, weighs and opposes each of the parts before casting them in their final form. And, with this methodical and ordered construction of the different parts, Clarà obtains the harmony and fullness of the whole ${ }^{24}$-words that might still more justly have been applied to Maillol.

Of all the Catalan sculptors who found fresh inspiration in the climate of Noucentisme, ${ }^{25}$ Enric Casanovas combined the best of his early experiences among avant-garde circles both in Barcelona and in Paris with the new spirit of Mediterranean classicism. After a fairly insignificant start as a symbolist

${ }^{23}$ Eugeni d'Ors, in La Veu de Catalunya (24 December r9ro).

${ }^{24}$ Junoy, 24.

${ }^{25}$ My discussion is limited to the sculptors, especially Casanovas, whose work was essential to the formulation of Noucentista theory. There were, of course, other Catalan sculptors whose work was associated with Noucentisme, including Emili Fontbona, Juli González, Pau Gargallo-see Francesc Fontbona, «Pau Gargallo i el Noucentisme», Gargallo: Exposició del Centenari, Barcelona, I98I - and Manolo, although Manolo's work was seen for the first time in Barcelona only in 1917. 
writer, ${ }^{26}$ Casanovas turned to sculpture. His work was first included in a group show in Barcelona in 1902 , one that already aligned art with nationalism, "Art i Pàtria», and in I903 he shared a show with two painters (Manuel Ainaud and Claudi Grau) which was one of the last exhibitions to be held at Els Quatre Gats, the tavern which had been at the turn of the century a hotbed of Modernista activity and the vital link between the Catalan capital and Paris. In a review of the Quatre Gats show Barcelona's leading critic already detected a new direction, a departure from Modernista decadence in favour of a new emphasis on structure. ${ }^{27}$ Nevertheless, Casanovas's sculpture still reflected the loose, organically inspired surface handling that he had admired in the work of his teacher Josep Llimona. Moreover, his work was still anecdotal in the Modernista, symbolist, sense of the evocation of mood. Like Picasso and so many others in the Quatre Gats circle, however, Casanovas saw the realization of his artistic future in Paris. As it turned out, he would be hailed as Barcelona's leading sculptor, but not for another seven years: first Casanovas had to experience French art at first hand.

Casanovas's arrival in Paris in 1904 was propitious for the development of his sculpture; not only would he arrive in time to see Maillol's work at the Salon d'Automne (both in that year and La Mediterranée in I905), but he renewed his friendship with Quatre Gats artists, including Manolo and Picasso. Within a year or so they were all friends of Moréas, whose École Romane ideas were to influence their sculpture and (in the case of Picasso) painting in those years. Manolo, especially, who was an admirer of the work of Maillol, ${ }^{28}$ espoused Moréas's

${ }^{26}$ See, for example: Enric Casanovas, «Desvari», Joventut (24 October I90I).

${ }^{17}$ Raimon Casellas, «Notas d'art: Quatre Gats», La Veu de Catalunya, rg March 1903.

${ }^{28}$ According to Blanch, 20, Manolo frequently visited the collector Maurice Fabre, who owned works by Maillol as well as Cézanne and Van Gogh. 
challenge to return art to its Mediterranean origins, although he himself actually produced little sculpture in Paris, mostly for lack of funds. But after his move to Ceret in French Catalonia in I9 Io under the financial protection of his patron Frank Haviland, Manolo (like Maillol had done) began to celebrate the image of the local women as well as subjects of Mediterranean-mythological inspiration.

When Picasso decided to spend the summer in Spain in 1906 (Vollard had recently purchased a large group of works, providing the artist with the necessary funds to travel), he consulted Casanovas about a suitable place to work. The choice of Gósol, located in the mountains of Catalonia near the border with Andorra, away from his friends and commitments in Paris or Barcelona, was to prove critical for the artist, who had found his own so-called Rose period a kind of dead end. Symbolism had run its course, and Picasso felt the need to return to his roots (as he would do over and over again in his work) in order to break new ground. Moreover, in line with ideas about ancient cultures-which would no doubt have appealed to Casanovas - the remote village of Gósol represented a relatively untouched, primitive society: the kind of model from which modern Catalonia, its land and its people, derived their strength. In both literary and artistic terms the image of the strong, local woman rooted to the land came to represent the whole of Catalan culture. Not surprisingly, during his stay from late May to mid-August Picasso himself turned to the subject of the female nude and to the local types he found in Gósol. And, while the presence of Fernande Olivier, who had accompanied him there, is always felt, one cannot discount the influence of the image of the strong Mediterranean woman in the drawings and paintings of monumental nudes Picasso did upon his return to Paris that year. In addition, in Gósol Picasso began to interest himself in sculpture. ${ }^{29}$

29 Before 1906 Picasso's experience of sculpture had been limited to a 
Casanovas had intended to visit Picasso and Fernande during that summer, but letters from Picasso to the sculptor, who had stayed in Barcelona to look after his ailing mother, suggest that he left Gósol before Casanovas could join him. ${ }^{30}$ Part of their plan had been to work on sculpture (Picasso was also corresponding to Manolo), and it would have been quite consistent with Picasso's behaviour to want to avail himself of Casanovas's greater sculptural training at a juncture when he himself wanted to extend his limited technical knowledge of sculptural method. In late June Picasso wrote to Casanovas requesting him to send him some eines (chisels) to carve a piece of wood the villagers had found for him; but later letters indicate the tools never arrived. Picasso did do some primitive carving on pieces of shaped boxwood, ${ }^{3 \mathrm{x}}$ and their crude if not magical power certainly alerted him to the possibility of harnessing archaic and other primitive forms to his developing imagery.

Casanovas must have made the trip to Gósol himself some time after Picasso's departure, for several years later he worked on a stone bust, known as the Gósol Woman, which reflects his own commitment to Mediterranean sources. ${ }^{32}$ Especially in archaic classical works, Casanovas discovered the creative basis to express both the origins of his own Catalan culture and at the same time to come up with forms that lent themselves to modern interpretation. From 1907 Casanovas alternated residence between Paris and Barcelona, exhibiting his work in both cities; and in rgro he also began his frequent visits to

few small works, later cast in bronze, that he had done with the advice of Emili Fontbona.

${ }^{30} \mathrm{I}$ wish to express my most sincere thanks to Claudi Casanovas for making these letters available to me.

${ }^{3 .} \mathrm{Nu}$ aux bras levés, Musée Picasso, Paris, no. 232 and Buste de femme (Fernande), Musée Picasso no. 233.

32 Reproduced in Teresa Camps, «Aproximació inicial a la temàtica emprada per Enric Casanovas», Enric Casanovas, Barcelona, 1984, 43. 
Manolo in Ceret. But it was in his first individual show in I9I I in Barcelona at the Faianç Català galleries that Casanovas assumed his leadership of the new Noucentista movement in sculpture.

Casanovas'a reputation as a Noucentista was promoted over the next years, at a time when he was producing work of exceptional quality. Junoy wrote of his extraordinary ability to synthesize the spirit of the archaic with the modern in I9I 2: "Casanovas admires both the vital essence of works that are called archaic and, above all, their dense and solid architecture. From across the centuries he revives, or, better, creates, a sculpture that is genuinely primitive...» Junoy likens his figures to «flowers of stone from ancient times when the looks of the men were more direct and the gestures of the women slower»."3

One of the general principles of cultural Noucentisme was the concept of l'obra ben feta-the well-made work-be it an educational system or a sculpture. In this sense Junoy goes on to say of Casanovas that his sculptures reflect not only the artist's own healthy and vigorous temperament, but that the ideas and forms themselves are expressed through measured and constant harmony. The treatment of the materials (Casanovas preferred to work in stone and marble), for instance, is so well handled that «one sees the musculature beneath the strong forms-square, smooth, hard like steel, but at the same time touched by an inborn grace that is completely his own». ${ }^{34}$ The temperament of the artist is invoked as a model for society.

After a trip to London in 1913 to study ancient art at the British Museum, Casanovas finally returned, like so many of his compatriots, to live in Catalonia at the beginning of World War I. The affinity that he and Joaquim Sunyer, the leading Noucentista painter, felt for each other led to the most fruitful

33 Junoy, 13-14.

34 Ibid., 14. 
collaboration of their respective careers when, in 1915 -I917, they shared a studio on the island of Mallorca. There Casanovas produced works such as Pagesa mallorquina, in which the synthesis between the archaic and the contemporary is fully realized: the Catalan/Latin woman is at once the woman of the sea (as Mistral might have celebrated her) and also her ancient ancestor (the form itself evokes the Iberian model of La Dama de Elche). The simplified features and the revelation of the structure of the head through essential geometry, and also the choice of local, Mallorcan stone (left rough in the areas around her hair and Mallorquin headscarf) communicate the strength of her origins in art and culture-and, in the Noucentista sense, her race.

The war years represent for the Noucentista movement a new chapter in its development. For one thing the international art world came to neutral Spain: artists seeking relief from wartime centres, especially Paris and as far away as Russia, took up residence in Barcelona, Sitges and Madrid. Picasso, too, returned briefly in $19 x 6$ and spent over six months in I9I 7 in Barcelona, where his own neo-classicism found a sympathetic climate for its development. The impact of the avant-garde in exile (including not only Picasso but Picabia, Delaunay, Cravan and others) on the local art scene was to change the direction of young artists, such as Joan Miró, who, championed as a Noucentista in his first exhibition in 1916 , went on to revitalize and open new directions in his own work and in Catalan art as a whole.

As I have argued, the specifically twentieth-century, Mediterranean, form of classicism, which had its origins in a combination of formal and political ideas, found its first artistic expression in sculpture-specifically that of Maillol and the Catalan Noucentistes. This primacy of sculpture may well have been due to the fact that artistic models were more readily accessible-both physically and spiritually - than in painting. However, just as the political movement that accompanied and 
encouraged its rise became entrenched in a conservatism that belied many of its idealistic origins, so the vital force of the artistic movement of Noucentisme was shortlived. After 1920 artists either broke free of the movement-like Gargallo or González-or their work largely remained bound by the limits of its original conception. It was left to other artists to develop further the formal and political implications of classicism in the post-war world. 